\title{
PELAKSANAAN KEPEMIMPINAN KEPALA DISTRIK DALAM PENYELENGGARAAN ORGANISASI (Studi Kepemimpinan Distrik Sorong Barat Kota Sorong)
}

\author{
Agil Saeni ${ }^{1}$, Ana Lestari ${ }^{2 *}$ \\ ${ }^{1}$ Program Studi Ilmu Administrasi Negara, Universitas Muhammadiyah Sorong, Indonesia \\ ${ }^{2}$ Program Studi Ilmu Administrasi Negara, Universitas Muhammadiyah Sorong, Indonesia \\ *Korespondensi: alannalestari034@gmail.com
}

\begin{abstract}
Implementation The Leadership of subdistrick in Organizing. this research aims to identity and analyze the implementation the of the leadership of the District Head in organizing the organization in the West Sorong District, Sorong City. The research was conducted in the Sorong City. in this case, at the West Sorong District Office with consideration of the components of the problem were studied. this research is Using a qualitative approach, and the data collection in this research were obsevation, interviews and literatur study, where the data obtained were analyzed using qualitative methods. The results of the study show that the Head of Subdistrict of West Sorong has optimally implementation his leadership role in applying appropriate leadership principles or techniques in organizing the organization. the ability to increase the work productivity of his employees to achieve targets according to their responsibilities and authorities and the ability of the District Head to create job satisfaction for his employees. The ability of the employees of the West Sorong District office to adjust to various demands for aspirations and changes that occur in the West Sorong District Government environment is fully supported by implementation the leadership of Subdistrict, especially in administrative services so as to have an impact on improving overall employee performance.
\end{abstract}

Keyword : Leadership, Organization

\begin{abstract}
ABSTRAK
Pelaksanan Kepemimpinan Kepala Distrik Dalam Penyelenggaraan Organisasi. Penelitian bertujuan untuk Mengetahui dan menganalisis pelaksanaan kepemimpinan Kepala Distrik dalam penyelenggraan organisasi pada Distrik Sorong Barat Kota Sorong. Penelitian dilakukan di wilayah Kota Sorong, dalam hal ini di Kantor Distrik Sorong Barat dengan pertimbangan terhadap komponen-kompenen permasalahan yang diteliti. Menggunakan Pendekatan kualitatif, Metode pengumpulan data yang dilakukan dalam penelitian adalah observasi, wawancara, dan studi pustaka, dimana data yang diperoleh dianalisis menggunakan metode kualitatif. Hasil Penelitian menunjukkan Kepala Distrik Sorong Barat telah optimal melakukan pelaksanaan kepemimpinannya dalam menerapkan prinsip-prinsip atau teknikteknik kepemimpinan yang tepat guna dalam penyelenggaraan organisasi, hal tersebut ditandai dengan kemampuan Kepala Distrik dalam meningkatkan kemampuan pegawai menyesuaikan diri terhadap berbagai tuntutan dan perubahan yang terjadi, kemampuan dalam meningkatkan produktifitas kerja pegawainya untuk mencapai target sesuai tanggung jawab dan kewenangannya serta kemampuan Kepala Distrik dalam menciptakan kepuasan kerja bagi para pegawainya. Kemampuan para pegawai kantor Distrik Sorong Barat dalam menyesuaikan diri tehadap berbagai tuntutan aspirasi dan perubahan yang terjadi di lingkungan Pemerintah Distrik Sorong Barat didukung sepenuhnya oleh pelaksanaan
\end{abstract}


kepemimpinan Kepala Distrik khususnya dalam pelayanan administrasi sehingga membawa dampak meningkatnya kinerja pegawai secara keseluruhan.

Kata kunci: Kepemimpinan, Organisasi.

\section{PENDAHULUAN}

Organisasi secara sederhana dapat dilihat sebagai perserikatan orang-orang yang usahanya harus dikoordinasikan, tersusun dari sejumlah subsistem yang saling berhubungan dan saling tergantung, bekerja sama atas dasar pembagian kerja, peran dan wewenang, serta mempunyai tujuan tertentu yang hendak dicapai. Begitu pula, pada Distrik/Kecamatan Sorong Barat Kota Sorong, yang merupakan organisasi publik atau instansi Pemerintah Daerah Distrik atau Kecamatan Sorong Barat. Organisasi pemerintah daerah ini berisikan karyawan/pegawai yang mempunyai serangkaian aktivitas yang jelas, dan dilakukan secara berkelanjutan guna mencapai tujuan organisasi. Semua tindakan yang diambil dalam setiap kegiatan diprakarsai, dan ditentukan oleh Sumber Daya Manusia (SDM)/SDM Aparatur yang menjadi anggota organisasi, dan SDM tersebut adalah pendukung utama di dalam organisasi tersebut.

Dalam mencapai tujuan institusi tersebut, diperlukan sumber daya baik sumber daya/resource berupa energi, tenaga, kekuatan, maupun pikiran yang diperlukan untuk menciptakan aktivitas ataupun kegiatan. Di samping itu, dalam organisasi tersebut juga terdapat kepemimpinan yaitu seseorang yang bertanggung jawab terhadap beroperasinya organisasi tersebut. Ditegaskan bahwa peran kepemimpinan pada Distrik Sorong Barat adalah bertanggung jawab mengarahkan apa yang baik bagi pegawainya, agar tujuan organisasi dapat tercapai tepat sasaran. Untuk itulah kepemimpinan yang baik sangat diperlukan bagi organisasi, dan adanya kepemimpinan yang baik tersebut, maka tujuan organisasi bisa terarah dalam proses mencapai tujuannya.

Kepemimpinan menurut Siagian (2005: 34) adalah kemampuan yang dimiliki seseorang untuk memilih tujuan yang tepat atau peralatan-peralatan untuk pencapaian tujuan yang telah ditetapkan. Dengan demikian, suatu organisasi masa kini dengan sumber daya manusianya yang makin luas pandangannya, makin tinggi kemampuannya dan semakin kritis terhadap situasi lingkungan sehingga benar-benar cukup komplek. Untuk itu diperlukan sosok pemimpin yang handal di antaranya yang 
mampu menentukan tujuan dengan ketepatan peralatan yang ada. Selanjutnya, melakukan pembagian tugas ataupun pembagian kerja yang akurat dan tegas, sehingga merupakan kegiatan yang terpadu dan benar-benar tercermin adanya keterkaitan yang harmonis antara subsistemsubsistem organisasi.

Distrik adalah pembagian wilayah administratif yang terdapat pada Provinsi Papua dan Papua Barat di bawah kabupaten atau kota. Istilah Distrik menggantikan sebutan kecamatan yang sebelumnya digunakan seperti halnya di provinsiprovinsi lain di Indonesia. Penetapan ini menyusul diterapkannya Undang-undang Nomor 21 Tahun 2001 tentang Otonomi Khusus bagi provinsi Papua dan Papua Barat. Distrik merupakan perangkat daerah Daerah Kabupaten atau Kota di Papua dan Papua Barat yang mempunyai wilayah kerja tertentu yang dipimpin oleh seorang Kepala Distrik. Distrik dibagi lagi menjadi sejumlah kampung atau nama lain sesuai dengan adat istiadat setempat. Pembentukan, pemekaran, penghapusan atau penggabungan distrik ditetapkan dengan Peraturan Daerah Kabupaten atau Kota.

Prinsip-prinsip dalam memimpin tersebut menurut Steers (2002:206) harus memenuhi beberapa kriteria atau indikator yang dapat digunakan untuk menilai atau mengukur fungsi organisasi yang sedang dipimpin, yaitu; a) Kemampuan menggerakkan organisasi untuk menyesuaikan diri; b) Kemampuan meningkatkan produktivitas; c) Kemampuan menciptakan kepuasan kerja.

Berkaitan dengan betapa pentingnya konsep kepemimpinan yang ada di kantor Distrik Sorong Barat perlu menggali informasi untuk mengetahui dan menganalisa pelaksanaan kepemimpianan Kepala Distrik serta untuk mengetahui dan menganalisa kendala-kendala Kepemimpinan Kepala Distrik baik secara internal maupun eksternal dalam penyelenggaraan organisasi.

\section{METODE PENELITIAN}

Penelitian ini dilakukan di wilayah Kota Sorong, dalam hal ini di Kantor Distrik Sorong Barat dengan pertimbangan terhadap komponen-kompenen permasalahan yang diteliti. Menggunakan Pendekatan kualitatif, Metode pengumpulan data yang dilakukan dalam penelitian adalah wawancara, studi pustaka dan observasi, dimana data yang diperoleh dianalisis menggunakan metode kualitatif. Penelitian ini dimaksudkan untuk menemukan Fakta-fakta tentang pelaksanaan Kepemimpinan dalam penyelenggaraan organisasi pada Distrik Sorong Barat Kota 
Sorong. Selanjutnya melakukan interpretasi secara tepat, dan akurat sifat dan tindakan dari kelompok maupun individu. Pendekatan/desain yang digunakan dalam penelitian ini adalah pendekatan kualitatif, karena mengamati dan menangkap realitas dan mengkaji perilaku individu dan kelompok serta pengalaman informan.

\section{HASIL DAN PEMBAHASAN}

Hasil interpretasi dapat dinilai melalui katagori tinggi, sedang dan rendah. Hasil interpretasi dinilai tinggi apabila ditandai adanya penyesuaian tugas pokok dan fungsi organisasi dengan peraturan yang berlaku, adanya uraian tugas yang berlaku, adanya pendelegasian wewenang dan adanya petugas khusus yang ditunjuk. Begitu juga terhadap pencapaian semua target yang dibebankan kepada organisasi, dan tidak terjadi keluhan pegawai, baik terhadap suasana kerja, beban tugas dan tanggungjawab, lingkungan kerja, proporsi insentif yang diterima dan lain-lain. Pemimpin berdasarkan konsep teoritis memiliki tanggung jawab yang besar dalam suatu birokrasi. Dengan demikian peranan pemimpin sangat penting dalam usaha mencapai tujuan suatu organisasi, sehingga dapat diketahui keberhasilan atau kegagalan yang dialami, sebagian besar ditentukan oleh kualitas kepemimpinan.
Kepemimpinan Kepala Distrik harus sepenuhnya melakukan peran yang menerapkan prinsip atau teknik kepemimpinan yang tepat kepada para pegawainya serta optimal dalam meningkatkan kemampuan pegawai untuk menyesuaikan diri terhadap berbagai tuntutan dan perubahan yang terjadi.

\section{Kemampuan Menyesuaikan Diri}

Penyesuaian diri merupakan sebuah usaha yang dilakukan oleh individu untuk menyelaraskan kebutuhan, harapan, dan tuntutan dirinya terhadap lingkungannya. Penyesuaian diri mencakup perubahan dalam diri sendiri dan lingkungan yang diperlukan untuk mencapai hubungan yang memuaskan dengan orang lain dan lingkungan sekitar. Kantor Pemerintahan Distrik Sorong Barat sebagai salah satu institusi pelayanan publik dituntut memiliki kemampuan menyesuaikan diri agar memiliki pegawai yang mampu menunjukkan kinerja yang tinggi, sehingga terwujud efektivitas pelayanan yang maksimal. Tugas dan fungsi organisasi Pemerintah Distrik Sorong Barat dalam pelayanan publik khususnya bidang pengurusan administrasi, dapat diketahui dengan melakukan penilaian terhadap kinerja beberapa seksi salah satunya adalah seksie pemerintahan, yang mendapat tugas 
dan tanggungjawab khusus dalam memberikan pelayanan pengurusan tanah adat kepada masyarakat Distrik Sorong Barat. Berdasarkan data yang diperoleh melalui observasi dan wawancara kepada Kepala Distrik dan seksi Pemerintahan Distrik Sorong Barat, yang kemudian dilakukan penilaian melalui parameter yang telah ditentukan di atas, dapat diketahui bahwa kemampuan menyesuaikan diri para pegawai di Kantor Distrik Sorong Barat, khususnya dalam memberikan pelayanan administrasi kepada masyarakat telah didukung sepenuhnya oleh Kepala Distrik, Sehingga mendapat apresiasi dari masyarakat setempat, terutama terhadap kinerja para pegawai dan kepemimpinan Kepala Distrik . Hasil wawancara informan dapat diketahui bahwa, untuk mengurus administrasi ditetapkan waktu penyelesaian melalui pelayanan yang cepat. Apabila persyaratannya lengkap dan Kepala Distrik yang akan menendatangani formulir permohonan kepada instansi pelaksana berada ditempat, maka waktu untuk memproses administrasi di Distrik Sorong Barat hanya memakan waktu paling lama 10 (sepuluh) menit hingga 1 (satu) jam. Menurut informan keberadaan Kepala Distrik yang selalu berada di tempat sangat memudahkan setiap pengurusan administrasi, kedisiplinan yang ditunjukkan
Kepala Distrik memacu pegawai pada Distrik Sorong Barat lebih baik dalam hal kedisiplinan. Selanjutnya berdasarkan observasi selama penelitian ini berlangsung, pelayanan pada kantor Distrik Sorong Barat antara lain Pengurusan Tanah yaitu surat pelepasan hak atas tanah adat dan surat keterangan kepemilikan atau garapan tanah, pengurusan penyaluran beras miskin (raskin), surat keterangan kematian, surat keterangan ijin pemakaman, surat keterangan ahli waris, surat ijin usaha, surat keterangan ijin penelitian mahasiswa, surat keterangan pensiunan PNS, surat keterangan domisili bahkan surat keterangan kepemilikan kapal. Adapun untuk Pengurusan e-KTP sudah tidak dilayani pada kantor Distrik tetapi diambil alih oleh Kantor Kependudukan dan Catatan Sipil. Pelayanan yang mengupayakan konsep pelayanan optimal dan mengedepankan kepentingan masyarakat, menggambarkan tingkat kemampuan menyesuaikan diri para pegawai pada setiap seksi untuk pelayanan publik, Dalam hal ini pelayanan yang diberikan mengutamakan kepuasan dan keadilan bagi masyarakat sebagai pengguna jasa. Dalam penelitian ini terlihat bahwa 2 (dua) seksi yaitu seksi Pemerintahan dan seksi Perekonomian dan Pembangunan adalah seksi yang paling membutuhkan perhatian sebab sangat berhubungan dengan 
kepentingan masyarakat dan membutuhkan ketelitian yang tinggi dari pegawai yang terlibat dalam seksi tersebut, dari hasil wawancara menunjukkan kemampuan kinerja dari kantor distrik yang responsif terhadap masukan dari masyarakat sehingga pelaksanaan tugas lapangan dapat terselesaikan dengan baik. Kemampuan pegawai Kantor Distrik Sorong Barat dalam mengenali, merespon dan melakukan perubahan atas tuntutan dan aspirasi masyarakat cukup tinggi. Hal tersebut dapat dilihat dengan adanya sarana dan saluran komunikasi untuk menampung keluhan masyarakat. Menurut informan bahwa, Pemerintahan Distrik Sorong Barat bahwa saran, keluhan dan aspirasi yang disampaikan, baik secara langsung maupun tidak langsung biasanya akan dibahas untuk direalisasikan dalam bentuk kebijakan, kegiatan maupun prosedur pelayanan. Gambaran tentang parameter kecepatan waktu pelayanan dan keramahan petugas, antara lain dikemukakan oleh masyarakat yang mengurus permohonan, Warga Danau maninjau Kelurahan Rufei mengatakan bahwa pelayanan administrasi sangat cepat dan tidak memakan waktu lama.

Hasil wawancara kepada sejumlah informan dan hasil observasi selama penelitian ini berlangsung kemampuan menyesuaikan diri para pegawai Kantor
Distrik Sorong Barat, khususnya dalam pelayanan administrasi dikatagorikan sangat baik. Kepala Distrik Sorong Barat telah optimal melakukan peran kepemimpinan guna meningkatkan kemampuan menyesuaikan diri para pagawainya. sehingga berdampak meningkatnya kinerja pegawai secara keseluruhan.

\section{Kemampuan}

Meningkatkan

\section{Produktivitas}

Produktifitas adalah kemampuan pegawai dalam mengelola dan memanfaatkan sumberdaya yang dimiliki agar memperoleh keluaran atau hasil yang optimal dalam rangka pelaksanaan tugas yang dibebankan kepadanya untuk mencapai hasil kerja yang telah ditentukan.

Berdasarkan hasil penelitian ini, terdapat kegiatan yang bertujuan memberikan bimbingan dan arahan kepada pegawai, baik dalam bentuk apel, upacara maupun rapat-rapat pembinaan. Pengarahan dan bimbingan Kepala Distrik kepada pegawainya baik bersifat personal maupun kolektif dalam melaksanakan pekerjaan. Hal ini dimaksudkan agar pegawai memperoleh hasil kerja yang optimal dalam rangka pelaksanaan tugas yang telah dibebankan dan evaluasi terhadap pencapaian hasil kerja yang telah ditentukan. 
Memperhatikan hasil di atas, menunjukkan bahwa Kepala Distrik telah mamanfaatkan keberadaan struktur organisasi yang tersedia dalam berkoordinasi dan dalam melakukan instruksi. Sehingga dalam melaksanakan tugas pokok dan fungsinya, para pegawai berpedoman pada aturan yang berlaku dengan mengacu pada mekanisme dan budaya kerja yang telah dibentuk oleh Kepala Distrik. Merujuk pada hasil wawancara dapat diketahui bahwa jenisjenis apel dan upacara yang selalu menjadi agenda rutin Kantor Distrik Sorong Barat adalah sebagai berikut; 1) Kewajiban apel pagi hari senin pada kantor Walikota Sorong; 2) Apel setiap hari Selasa pagi pada Kantor Distrik Sorong Barat yang dihadiri oleh Lurah dalam lingkup distrik Sorong Barat.

Sedangkan kegiatan rapat dalam rangka pembinaan dan peningkatan produktivitas kerja yang menjadi agenda rutin Kantor Distrik Sorong Barat, adalah sebagai berikut; a) Rapat rutin setiap akhir bulan atau tiga bulanan; b) Rapat khusus jika dibutuhkan dan bersifat mendesak.

Selain kegiatan pembinaan melalui apel, dan rapat-rapat tersebut menurut Kepala Distrik Sorong Barat, masih ada beberapa kegiatan pembinaan secara rutin dan berkesinambungan seperti gotongroyong pada waktu tertentu dan kunjungan kepada masyarakat yang tertimpa musibah maupun kunjungan untuk meninjau lokasi yang bisa diperuntukkan untuk dana Rencana Strategi Pembangunan Kampung (Respek) yang akan diprioritaskan. Program Respek merupakan kegiatan perencanaan yang bersifat strategis karena memiliki batasan waktu dan target-target tertentu yang pencapaiannya diharapkan bisa mengubah kualitas hidup masyarakat partisipan. Perbedaan spesifik program respek ini dengan rencana Pemerintah lainnya adalah masyarakat menjadi aktor utama dalam hampir semua tahapan program. Oleh karena itu Kepala Distrik melakukan kunjungan untuk menfasilitasi masukan-masukan dari masyarakat terutama masyarakat pribumi sebelum program-prgram tersebut digulirkan.

Berdasarkan keterangan informan diketahui bahwa, Pemerintahan Distrik Sorong Barat sejak tiga tahun terakhir ini mengalami banyak kemajuan karna pendekatan yang dilakukan Kepala Distrik lebih bersifat kekeluargaan sehingga motivasi pegawai Kantor Distrik Sorong Barat dalam bekerja semakin meningkat yang mengakibatkan mekanisme dalam proses pelayanan dan pekerjaan banyak mengalami kemajuan, produktivitas kerja 
pegawai secara keseluruhan pun mengalami peningkatan. Berdasarkan kondisi ini dapat diprediksikan bahwa Kepala Distrik Sorong Barat sudah optimal dalam meningkatkan produktivitas kerja pegawainya. Bahkan mekanisme dan budaya kerja yang terbentuk berubah total. Dampaknya selain berpengaruh secara langsung pada meningkatnya motivasi kerja pegawai yang mengakibatkan perbaikan secara umum, juga banyak menimbulkan kepuasan masyarakat akibat banyak pekerjaan yang terselesaikan secara cepat dan baik.

\section{Kemampuan Menciptakan Kepuasan Kerja}

Kepuasan kerja merupakan cara pegawai merasakan dirinya atau pekerjaannya. Dapat disimpulkan bahwa kepuasan kerja adalah perasaaan yang menyokong atau tidak menyokong dalam diri pegawai yang berhubungan dengan pekerjaan maupun kondisi dirinya. Perasaan yang berhubungan dengan pekerjaan melibatkan aspek-aspek seperti upaya, hubungan dengan pegawai lain, kesempatan pengembangan karir, penempatan kerja dan struktur organisasi.

Berdasarkan hasil wawancara diperoleh keterangan bahwa kepuasan kerja pegawai bersifat relatif. Mengacu pada hasil dokumentasi terhadap arsip dokumen pelaksanaan anggaran SKPD Distrik Sorong Barat tahun anggaran 2015, bahwa APBD Kota Sorong mengalokasikan anggaran untuk SKPD Distrik Sorong Barat sebesar RP. 6.593.222.579,- (Enam Milyar Lima Ratus Sembilan Puluh Tiga Juta Dua Ratus Duapuluh Dua Ribu Lima Ratus Tujuh Puluh Sembilan Rupiah), yaitu untuk belanja tidak langsung sebesar Rp.5.443.222.576,(Lima Milyar Empat Ratus Empat Puluh Tiga Juta Dua Ratus Dua Puluh Dua Ribu Lima Ratus Tujuh Puluh Enam Rupiah) dan belanja langsung sebesar Rp.1.150.000.000,- (Satu Milyar Seratus Lima Puluh Juta Rupiah). Anggaran belanja tidak langsung tersebut, dialokasikan untuk setap triwulan sebesar Rp. 1.360.806.000,pembayaran gaji dan tunjangan pegawai dan untuk pembayaran tambahan penghasilan pegawai, Sedangkan anggaran belanja langsung dialokasikan untuk program pelayanan administrasi perkantoran, program peningkatan sarana dan prasarana aparatur, program peningkatan kapasitas sumber daya aparatur dan program peningkatan partisipasi Masyarakat dalam pembangunan desa. Adapun waktu kerja seluruh instansi di lingkunagn Pemerintah Distrik Sorong Barat mulai jam 08.00 WIB sampai jam 15.00 WIB, hari kerja mulai Senin sampai Jumat, sedangkan hari Sabtu 
dan Minggu libur. Berdasarkan hasil penuturan sejumlah informan menunjukkan bahwa bahwa Pelaksanaan kepemimpinan Kepala Distrik Sorong Barat sudah optimal dalam menciptakan kepuasan kerja bagi pegawainya. Kepala Distrik dianggap sangat reaktif terhadap masukan dan usulan terutama dari pegawai honorer, Dampaknya antara lain banyak pegawai yang disiplin memanfaatkan jam kerja, banyak pegawai menyatakan kepuasannya dibawah kepemimpinan Kepala Distrik saat ini. Salah satu penyebabnya adanya komunikasi atau pembinaan yang berjalan sebagaimana mestinya dan seringnya Kepala Distrik menyampaikan informasi apa saja yang dianggap penting kepada para pegawai ketika selesai melakukan rapat koordinasi dengan SKPD lain atau walikota, baik informasi terbaru maupun peningkatan pelayanan.

Menurut informan dalam hal kehadiran, Kepala Distrik saat memeriksa ada pegawai yang tidak hadir pada jam kantor biasanya melakukan hubungan melalui telephon selluler dengan mengirimkan SMS kepada pegawainya menanyakan alasan tidak hadir pada jam kantor, sehingga pegawai merasa terkontrol dan selalu dalam pengawasan.

Cara yang dilakukan Kepala Distrik
Sorong Barat dalam pengawasan disiplin ini sudah dilakukan sejak diberi mandat memimpin Distrik Sorong Barat oleh Walikota Sorong.

Faktor yang Menjadi Kendala Kepemimpinan Kepala Distrik

Internal : Perbedaan latar belakang pendidikan pada sumber daya manusia atau pegawai. Dalam upanya untuk meningkatkan kinerja para pegawai, Kepala Distrik Sorong Barat mengalami kendala yang bersifat internal, dimana kendala tersebut muncul dari tingkat pendidikan masing-masing pegawai yang berbeda. Oleh karena itu menurut penuturan dari Kepala Distrik bahwa dari perbedaan tingkat pendidikan ini menjadi pengaruh yang cukup menonjol dalam memberikan pemahaman kinerja pada masing-masing pegawai. Namun hal ini dapat diatasi melalui pendekatan personal dengan pendekatan kekeluargaan dalam memberikan pemahaman.

Eksternal : Selain hambatan yang muncul dari faktor internal, ternyata hambatan lain juga ada yaitu secara eksternal. Hambatan ini di sebabkan dari adanya masalah pribadi seperti keadaan ekonomi pada diri pegawai itu sendiri. Keadaan atau kondisi ekonomi merupakan 
salah satu hal yang mungkin dapat mempengaruhi kehidupan pegawai baik didalam atau diluar lingkungan kantor. Mengatasi hal tersebut Kepala Distrik maupun sekretaris distrik berperan dalam melakukan pendekatan personal sehingga kendala-kendala tersebut sejauh ini masih dalam tahap terkontrol dalam memberi pemahaman dan motivasi.

\section{SIMPULAN}

Kepala Distrik Sorong Barat telah optimal melakukan peran kepemimpinannya dalam menerapkan prinsip-prinsip atau teknik-teknik kepemimpinan yang tepat guna dalam penyelenggaraan organisasi, hal tersebut ditandai dengan ; 1) Kemampuan Kepala Distrik dalam meningkatkan kemampuan pegawai menyesuaikan diri terhadap berbagai tuntutan dan perubahan yang terjadi, kemampuan dalam meningkatkan produktifitas kerja pegawainya untuk mencapai target sesuai tanggung jawab dan kewenangannya serta kemampuan Kepala Distrik dalam menciptakan kepuasan kerja bagi para pegawainya. Kemampuan para pegawai kantor Distrik Sorong Barat dalam menyesuaikan diri tehadap berbagai tuntutan aspirasi dan perubahan yang terjadi di lingkungan Pemerintah Distrik Sorong Barat didukung sepenuhnya oleh peran kepemimpinan Kepala Distrik khususnya dalam pelayanan administrasi sehingga membawa dampak meningkatnya kinerja pegawai secara keseluruhan; 1) Dalam penyelesaian permasalahan, kepemimpinan Kepala Distrik di Distrik Sorong Barat sudah sangat baik dimana dalam melakukan pengambilan keputusan menggunakan gaya kepemimpinan situasional; 2) Pendelegasian wewenang pada kantor Distrik Sorong barat juga telah dilaksanakan dengan baik, adanya pelimpahan tugas dan wewenang yang luas kepada pegawai, dalam melakukan pengawasan cenderung tidak terlalu ketat karena menganggap para pegawainya telah mengetahui tugas yang diberikan dan ini merupakan implikasi dari kepemimpinan situasional. Kepala Distrik menganggap bahwa pegawainya sudah mampu mengendalikan diri dan mengawasi dirinya sendiri dalam bekerja.

\section{DAFTAR PUSTAKA}

Anoraga, P. 2000, Psikologi Kerja, Rineka Cipta: Jakarta.

Antoni, F. 2006, Pengaruh Gaya Kepemimpinan Orientasi Tugas dan Orientasi Hubungan terhadap Motivasi Kerja dan Dampaknya pada Prestasi Kerja Pegawai Pengadilan Tinggi Tata Usaha Negara Surabaya, [Tesis], Program Pascasarjana, Universitas 17 Agustus: Surabaya. 
Armstrong, Michael dan A. Baron, 2000, Performance Management The New Realities, Institute of Personnel and Development: London.

Aritonang, K. T. 2005, Kompensasi Kerja, Disiplin Kerja Guru dan Kinerja Guru SMP Kristen BPK Penabur, Jakarta, Jurnal Pendidikan Penabur No,04 / Th,IV/ Juli 2005.

Bacal, R. 2002, Performance Management, Gramedia: Jakarta.

Bernadin, H. John dan J. E. A. Russell, 1998, Human Resources Management: an Experiental Approach, $2^{\text {nd }}$ Ed, McGraw Hill: New York.

Blanchard, Miller, 2005. "The SecretRahasia Kepemimpinan”, Jakarta, Elex Media Komputindo.

Bolden, R., Gosling, J., Marturano, A. and Dennison, P. 2003. "A Review of Leadership Theory and Competency Frameworks. Centre for Leadership Studies", University of Exeter. UK.

Creswell, John W. 2002. Researh Design. Quanlitative \& Quantitative Approaches. New York: Sage Publication, Inc.

Cascio, F. W. 2000, Managing Human Resources: Productivity, Quality of Work Life, Profits, $5^{\text {th }}$ Ed, Irwin McGraw-Hill: Universitas Michigan.

Cushway, B. 2002, Human Resource Management, Gramedia: Jakarta.
Handoko, Hani.T. 2001. Manajemen Personalia \& Sumberdaya Manusia. Yogyakarta. Diterbitkan Oleh BPFE.

Haynes, P. dan F. Glenda, 2000, Human Resources Service Quality and Performance: a Case Study, International Journal of Contemporary Hospitality Management, MCB University Pr, Pp, 12, 4, 240 -248.

Hendel, Tova, Miri Fish \& Vered Galon, 2003. "Leadership style and choice of strategy in conflict Management among Israeli nurse managers in general hospitals", International Education Journal, Vol. 4 No. 3, 2003, http://www.iej.cjb.net.

Hamlin, R, 2007. "Developing effective leadership behaviours: the value of evidence based Management". Business Leadership Review IV:IV October 2007, UK.

Kerlinger, Fred N. 2000. Azas-azas Penelitian Behavioral. Alih Bahasa Landung R Simatupang. Yogyakarta: Gajah Mada University Press. Edisi Ketiga.

Kartono, Kartini, 2001. "Pemimpin dan Kepemimpinan”. Cetakan Ke sembilan, Jakarta: Raja Grafindo Persada.

Lemhannas, 2012. "Buku Modul Bidang Studi Kepemimpinan Nasional”. 
Locke, Edwin A, Shelley Kirkpatrick, Jill K. Wheeler, Jodi Schneider, Kathryn Niles, Harold Goldstein, Kurt Welsh, Dong-Ok Chah, 1991. "The Essence of Leadership, The Four Keys to Leading Successfully”, Lexington Books, New York.

Moleong, Lexy J. 2006. Meodologi Penelitian Kualitatif. Penerbit PT. Remaja Rosdakarya-Bandung. Cetakan Kesebelas.

Muchji, Moch dan B. Suko Priyono. 2011. "Pengaruh Gaya Kepemimpinan Transaksional Terhadap Kinerja Karyawan yang Di moderasi Gaya Kepemimpinan Transformasional" Telaah Managemen, Vol.1 Edisi 2, hal. 236- 256.

Malthis, R. dan H. J. Jackson, 2002, Manajemen Sumber Daya Manusia, Ed Ke-4, Salemba Empat: Jakarta.

Manullang, M. 2001, Manajemen personalia, Edisi Ke-3, UGM Pr: Yogyakarta.

Maryoto, S. 2000, Manajemen Sumber Daya Manusia, BPFE Pr: Yogyakarta.

Nawawi, 2003. Kepemimpinan Menggerakkan Organisasi, UGM Pr: Yogyakarta.

Nawawi, Hadari, dan Hadari, Martini. 2003. "Kepemimpinan Yang Efektif", Yogyakarta, Gadjah Mada University Press, Cetakan Pertama.
Nitisemito, 2002, Wawasan Sumber Daya Manusia Pustaka Utama Grafiti: Jakarta.

Newman, W Lawrence. 1997. Social Research Methods. Qualitative And Quantitative Approaches, United States Of America: Allyn and Bacon. Third Edition.

Ndraha, Taliziduhu, 2003. Metodologi Pemerintahan Indonesia, Cetakan III, Jakarta: Bina Aksara, hlm 57.

Sinamo, Jansen. 2005. Delapan Etos Kerja Profesional. Jakarta: Institut Mahardika.

Sugiyono, 2000. Metode Penelitian Administrasi, Penerbit Alfabeta, Bandung.

Siagian, S. 2002, Kiat Meningkatkan Produktivitas Kerja, Rineka Cipta: Jakarta.

Simamora, H, 2004, Manajeman Sumber Daya Manusia, Ed ke-3, Cet Ke-1, Sekolah Tinggi Ilmu Ekonomi YKPN Pr: Yogyakarta.

Steers, R.M. 2002. Efektifitas Organisasi (terjemahan H. Pujaatmaja) Jakarta: Erlangga.

Tella, A., C. O Ayeni dan S. O. Popoola, 2007, Work Motivation, Job Satisfaction, and Organisational Commitment of Library Personnel in Academic and Research Libraries in Oyo State, Nigeria, Library Philosophy and Practice 2007, ISSN 1522-0222, 2 Oktober 2010. 


\section{PROFIL SINGKAT}

Penulis lahir di Mekkah, 28 Desember 1974. Menyelesaikan pendiidkan Strata satu pada Fakultas Pertanian Universitas Cenderawasih tahun 1999, pendidikan Strata Dua pada program studi administrasi Universitas Muhammadiyah Jakarta tahun 2016. Aktivitas saat ini sebagai staf pengajar pada program studi administrasi negara fakultas Ilmu sosial dan Ilmu Politik Universitas Muhammadiyah Sorong. 